\title{
The board of directors and the corporate tax planning: Empirical Evidence from Tunisia
}

\author{
Aliani Khaoula (Corresponding author) \\ Fiesta, higher institute of management of Tunis, university of Tunis, \\ Tel: +216 98910 575, E-mail: alianikhaoula@yahoo.fr
}

Zarai Mohamed Ali

Department of accounting, higher institute of management Tunis, University of Tunis

E-mail: zaraimedali@yahoo.fr

Received: September 03, 2012 Accepted: October 17, 2012 DOI: 10.5296/ijafr.v2i2.2525

\begin{abstract}
Our study represents the first attempt to investigate whether board of directors' attributes have an impact on corporate tax planning in a developing country.

Using a sample of 32 companies listed on the Tunisian stock exchange market from 2000 to 2007, results indicate that duality and diversity on the board of directors significantly influences tax planning. Duality exhibits a negative relation with effective tax rates. However, diversity on the board shows a positive association. We don't find relations between board size, independent directors and corporate tax planning.

We contribute to the large literature on corporate tax planning by proposing that board's characteristics may have a substantial effect on reducing effective tax rates. We add a new angle to existing studies on corporate tax governance by involving board's diversity and sectorial effect. An implication of this study is that tax planning would be decreased by women's presence on the board of directors. In addition, tax incentives granted by the state to some sectors may improve tax strategies.
\end{abstract}

Keywords: Tax planning, effective tax rate, board's attributes, Tunisia 


\section{Introduction}

The literature on corporate tax planning has been growing gradually as new facets are added progressively due to the multidisciplinary of the subject. These facets can be classified into three major streams of literature. The first field of research focuses on studying relation between tax planning and firm characteristics. Several researches are conducted to investigate favorable characteristics for practicing tax planning such as size, profitability, leverage and capital intensity. (Stickney \& McGee 1982; Zimmerman 1983; Porcano 1986; Shevlin \& Porter 1992; Rego, 2003). Recent studies demonstrate that corporations with more extensive foreign operations, research and development expenditures and less leverage have lower effective tax rates. (Graham \& Tucker 2006; Wilson 2009; Lisowsky, 2010).

Based on recent theoretical research, Dyreng et al., (2010) started examining a second field of research concerning investigating the impact of CEO's characteristics on corporate tax planning. The third stream of research deals with corporate tax governance. An extensive literature has debated potential explanations for the interaction between the corporate governance and the tax planning over the recent decades. The succession of fiscal and financial scandals in Europe and United States has revived interest in reconsidering the effect of corporate governance mechanisms on tax planning.

Despite all of these prior research findings, we still have an incomplete understanding as to which factors related to corporate governance drive variation in tax avoidance across firms. Much is less known about the role of corporate governance in tax planning.

We will concentrate on the third field of research. Our study investigates whether characteristics of the board have effects on their firms' tax avoidance. Despite decade of empirical research in corporate taxation, little attention has been focused on whether board attributes have an effect on their firms' tax avoidance. Minnick and Noga (2010) were the first who investigate the impact of corporate governance mechanisms on tax planning in American context. Lanis and Richardson (2011) emphasized on the characteristics of the board effects on tax shelter in Australian companies.

In this study, we explore this new stream of research in developing countries, the Tunisian exception. Studies on Tunisian boards concentrated essentially on corporate performance. Even the importance of the board in the success of corporate tax planning, there doesn't exist any research which undertake interdependences between the characteristics of the board and taxation, especially tax planning. The objective of our study is twofold. One is underlying the predominance of intern corporate governance mechanisms such as the board in tax strategies. Two is contributing to tax research in developing country.

Our study is novel in a number of ways. Firstly, despite the recent calls for research into this subject (Minnick \& Noga, 2010; Lanis \& al., 2011), to our knowledge, we are the first to investigate the relations between the board of directors and tax planning in the Tunisian context. Secondly, our main contribution to the literature is to show the importance of the board in strategic tax decisions related to minimizing tax burdens. In particular, the evidence presented shows that board's characteristics influence the decision to practice tax planning. The firms with strong corporate governance are able to create successful tax minimization 


\section{MInstitute Macrothink $_{\text {Int }}$}

International Journal of Accounting and Financial Reporting ISSN 2162-3082 2012, Vol. 2, No. 2

strategies. We however, find no evidence to support that all board's attributes contribute to corporate tax minimization. Thirdly, our study involves the impact of gender diversity on the board of directors which is not discussed before in the tax context.

The rest of this paper is organized as follows. In the next section, we present the theoretical background on the interactions between corporate tax planning and board of directors and formulate our hypotheses. Then, we explain the sample formation process. Next, we describe the research design and report the empirical results. The final section concludes the paper.

\section{Literature Review and Hypotheses Development}

The last two decades have witnessed an explosion of interest in tax planning, yet there is surprisingly little empirical evidence and until recently there has been little research on corporate governance mechanisms' roles in tax planning. According to Arlen \& Weiss (1995), taxes can induce several agency issues through income retention. The academic literature presents several governance solutions to minimize conflicts between shareholders and managers. In this paper, we will focus on one internal mechanism of corporate governance such as board of directors. In what follows, we present a brief theoretical an empirical literature about the links between boards attributes and corporate tax planning.

The Tunisian financial market moves toward a reinforcement of the right of information. In addition, corporate governance rules encourage the improvement of the quality of transparency and disclosure.In this sense, the guide of good corporate practices of the Tunisian enterprises (2008) insists in the protection of the shareholders 'rights to a better transparency and disclosure. All firms that decide to adopt this guide should guarantee an equal treatment of all shareholders and have to make sure that all the shareholders have all the required information and all the ways that enable them exercise their rights.

According to Fama \& Jensen (1983), the board of directors is a significant corporate governance device used to ratify managerial decisions and monitor the corporation's major decisions and to hire, fire, and set the compensation policy of top managers within the corporation.

Tax philosophy is implemented by the board of directors. It should be aligned with the global strategy of the company. The board can choose adequate tax planning strategy, resulting in lower effective tax rates. The board of directors makes sure that the intern environment of the enterprise is favorable to tax planning strategies.

\subsection{Board size}

The earliest literature on board size argues that smaller board sizes are more effective monitors. (Jensen, 1993; Lipton \& Lorsch, 1992). Indeed, a small board could result in more coherent discussion, since expressing opinions and communication within a small group is generally easy and takes less time. Vafeas (2000) concluded that firms with the smallest boards have better monitoring abilities. Beasley (1996) indicates that the likelihood of financial statement fraud increases in larger boards.

However, another stream of research recognizes the interest of larger boards. Dalton \& Dalton (2005); Barnhart \& Rosenstein (1998) justified this interest and present several 
arguments such as: larger boards have a multitude of opinions than may enrich the debates. Furthermore, larger boards increase the diversity in terms of professional experience, backgrounds, gender and nationalities.

The number of directors sitting on the Tunisian board varies from three to twelve. According to the article 189 of CSC: "The public company is directed by a board of directors composed from at least three members and twelve at the most".

The governance guide of good practices of Tunisian companies (2008) stipulates that: Every firm is free to choose, according to its needs, the number of the members that compose the board of directors in the limits of the law.

The board of directors have to be restrained enough to help a rapid decision making and as large as possible in order to take advantage from the diversity of the competences and the experience of the members

Hypothesis 1: The size of the board is negatively correlated with tax planning.

\subsection{Director independence}

The Sarbanes-Oxley Act (2002) establishes strict new rules concerning corporate governance and assumes that firms with outside directors are more effective in monitoring management.

In Tunisia, the notion of non executive independents directors has been introduced in the article 196 of the commercial code. Furthermore, the quality of shareholder is not required to be a member of the board of a public company. The governance guide of good practices of Tunisian companies (2008) call firms to appeal to independent directors that should be chosen for their qualifications and expertise. To that purpose, this guide recommends that at least the third of the board members should be independents.

Much of the literature has focused on the advantages and disadvantages of independent directors. Also, they emphasize the importance of board competence as such, but rarely recognize its relevance for the tax planning. Prior governance literature shows that boards with more independent directors improve the corporate performance and the shareholder's wealth. (Yermack, 1996; Jensen, 1993)

The prior academic research has focused on the effects of board composition on corporate performance. However, much less attention has been paid to the question of how board characteristics can have an influence on corporate tax planning. The composition of the board of directors is a critical factor in establishing a board; it should ensures that the board attend to the common interests of all shareholders.

Erle (2008) claimed that the board of directors bears the ultimate responsibility for fulfilling the tax obligations of the corporation, and is involved directly in the corporate tax planning strategy.

Minnick \& Noga (2010) suggest that independent directors can reinforce tax management 


\section{Al Macrothink}

International Journal of Accounting and Financial Reporting

ISSN 2162-3082 2012, Vol. 2, No. 2

because they can provide useful knowledge and background from their own industry and experience.

Lanis \& Richardson (2011) show that appointing higher percentages of outside directors to the board is associated with increasing its effectiveness in monitoring function of the board. The research shows that corporations with more effective monitoring of management are less likely to be involved in corporate fraud; also non executive directors have little incentive to engage in this type of behavior. (Yermack, 2004; Fich and Shivdasani, 2007)

Beasley (1996) argue that the board composition differ between fraud firms and non fraud firms. He confirms that the percentage of outside directors on the board of director is lower for fraud firms compared to no-fraud firms in the American context. He also suggests that the inclusion of a high proportion of independent directors prevent from fraudulent actions.

Hypothesis 2: the presence of independent directors is positively associated with corporate tax planning.

\subsection{Duality}

Jensen (1993) suggests that the CEO duality increases the agency cost because the CEO cannot monitor the board separate to his personal interest. Indeed, it is important to separate the CEO and chair positions.

The governance guide of good practices of Tunisian companies (2008) recommends a separation between the functions of the chairman of the board and of the chief executive officer (CEO), and this in the interest of efficiency. This guide announces that when the board decides to cumulate both functions, he is called to justify to shareholders the reasons for this choice. Tunisian firm can choose a strict separation of functions as indicated by the article 215 of the commercial code of companies.

The research conducted to study the influence of duality on performance conclude a negative effect (Klein, 2002; Deli and Gillan, 2000). Farber (2005) and Sharma (2004) support the existence of a relationship between CEO duality and the likelihood of financial statement fraud.

Recently, Minnick \& Noga (2010) consider that firms presenting duality in the CEO position have less tax management and higher tax expense.

\section{Hypothesis 3: Duality is negatively associated with corporate tax planning}

\subsection{Gender}

The developing economies, such as India and China, and Middle East countries (Tunisia and Jordan) are beginning to recognize the importance of developing female talent up to the board level (Singh, 2008). 


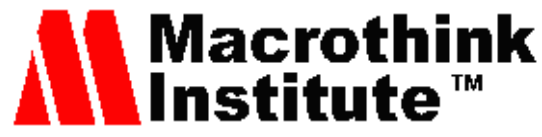

International Journal of Accounting and Financial Reporting ISSN 2162-3082

Croson and Gneezy (2008) show that the women are more risk averse than men, particularly in certain economical domains, and they are less involved than men in non-ethics behaviors. Kastlunger \& al., (2010) suppose that women should expose higher levels of tax compliance. Nevertheless, the men should show important levels of tax evasion. The tendency of the men for the evasion of taxes is explained by several factors as the social differences. The authors consider that the gender is responsible of the orientation of female and male concepts.

Mhamid \& al., (2010) argue that diversity on the board of directors boost performance. In the context of tax planning, Aliani \& al., (2011) were the first who introduce the issue of gender diversity and female values in Tunisia fiscal context. They conclude that the presence of women holds back the tax planning strategy within the firm.

Hypothesis 4: the diversity of the board is associated negatively with corporate tax planning.

\subsection{Performance}

The signal theory reveals another explanation of the relation between the effective tax rates and companies' profitability. This theory is introduced by Ross (1977) and it is based on information asymmetry. Firms can emit signals via their financial policy (their debt policy or dividend distribution) or their accounting policy. Saada (1993) indicated that signalling by the accounting contents can solve the problem of information asymmetry.

According to Raffournier (1990), companies which establish methods without tax incidence and reduce their results are considered the best. Firms, in the presence of tax incidence, seek to improve their accounting incomes. Since the accounting income appears among the most significant elements of financial accountancy, a good signal will then be transmitted to investors. Following this increase in the results, the fiscal burdens of these companies will increase and reciprocally the effective tax rates.

Hypothesis 5: the firm's profitability is associated positively with corporate tax planning.

\subsection{Sectorial effect}

The heterogeneity of the sectors of activities can induce different results concerning the variability of the corporate effective tax rates. In fact, the tax burdens change from one sector to another. The relation between the effective tax rates and the industrial sectorial effects was explored in some studies (Gupta and Newberry 1997; Kern and Morris, 1992; McIntyre and Nguyen, 2000; Omer and al., 1993 and Zimmerman (1983) but it often is treated as a subsidiary question and an adjustment factor.

Stickney and McGee (1982) conclude that the sectors related to the natural resources are treated in favorable manner than the other sectors. Omer \& al., (1993), Gupta and Newberry (1997), Nicodème (2002), Derashid and Zhang (2003), Janssen and al. (2005) and 


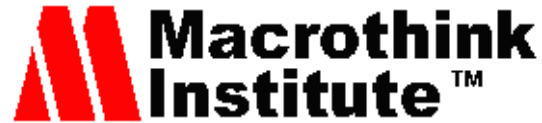

International Journal of Accounting and Financial Reporting

Vandenbussche and al. (2005) confirm that the effective tax rates vary considerably through the different sectors.

Derashid \& Zang (2003) are the first ones who put the accent on the relationship between the effective tax rates and the sectorial effects in the context of the United States. The results of these authors confirm the importance of the sectorial effect; firms belonging to the sectors of industry and tourism always pay less tax than other sectors. These findings are explained by the fact that the industrial policy protects the industrial sector. In addition, the State encourages the tourism sector.

\section{Data and Methodology}

\subsection{Sample selection}

To investigate the impact of corporate governance on tax planning, we use a sample comprised of 32 companies listed on the Tunisian Stock exchange, during the 2000-2007 period. Our data are extracted from the annuals reports collected and from the link of the BVMT (http://www.bvmt.com.tn). They will be organized in the form of panel data in order to increase the number of observations (because the number of listed company in 12 Tunisia is low)

In what follows, we present the variable definitions, the regression model and the results.

\subsection{Variable definitions}

\subsubsection{Dependent variable}

Plesko (2003) indicates that the measurement of the tax rate is a significant stage in research on taxation. Given the fact that the measures adopted by the researchers are different, the choice of such a measurement can have considerable effects on the obtained results. The literature exposed several types of the corporate effective tax rates (Plesko, 2003). The distinctions are made between the effective average tax rate and marginal tax rates. The relevance of each type depends on the studied research question. In our study, we retain the effective average tax rate to be able to consider the corporate fiscal burdens and to determine thereafter the various existing relations between this tax rate and the governance characteristics.

Following Dyreng et al. (2008) and Minnick \& Noga (2010), we calculate the annual GAAP ETR, which firms are required to disclose in their financial statements. The GAAP tax rate is defined as the ratio of total tax expense to pre-tax income for a given firm.

The size of the board of directors BSI is measured by the logarithm of the total number of directors that compose the board. The use of this measure is justified by the objective of mitigating heteroscedasticity problems.

To measure the degree of independence, we use the percentage of independent directors in the board (IND). Independent directors are directors who have no relationship with the management team (neither financial nor personal relationship). Richardon \& al., (2011) employ this variable to explore the effect of board of director composition on corporate tax aggressiveness. 


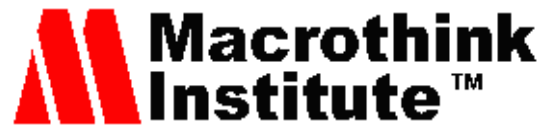

International Journal of Accounting and Financial Reporting

ISSN 2162-3082

2012, Vol. 2, No. 2

Return on assets (ROA) is measured as pretax income divided by total assets. We include this variable to control for overall performance and underline the specific effects of tax planning. (Dyreng \& al., 2008; Minnick \& Noga, 2010). Gupta and Newberry (1997) and Richardson and Lanis (2007) used this variable to measure the influence of profitability on tax rates 'variation.

Sector variable (SEC) is the sector dummy for services and industrial products. We include this variable in our analysis on the basis of arguments of previous researches. Derashid \& Zang (2003) conducted the first study to investigate the relationship between sectorial effect and the variation of effective tax rates of American firms. Aliani \& al., (2011) point out the importance of including this variable in their analysis related to corporate tax optimization in the Tunisian context.

Table 1 summarize the independent variables included in our model and the control variables.

Table 2 presents descriptive statistics for the 32 firm-years in our sample. The mean of effective tax rate is 0.1704 , with standard deviation of 0.1865 . This average shows that the effective tax rate of our sample is under the statutory tax rate (0.30). We find that Tunisian firms are characterized by the large size of the boards. On average the board has 10 directors. This size doesn't exceed the maximum number allowed by the CSC.

About 0.89 percent of board's members are independent. This descriptive result shows that the boards of Tunisian firms of our sample are dominated by independent directors.

In addition, statistics indicate that Tunisian CEOs has usually two functions: chief executive director and board chairman.

Table 3 presents the correlation matrix of independent variables. This table reports the correlation coefficients with the p-value of independent variables. The correlation among all independent variables are lower than 0.4 , the highest correlation coefficient is 0.319 between independent directors and diversity on the board of directors. The smallest coefficient (0.010) between board size and diversity is not significant. The result of correlation tests shows a weak link between the different variables as the Pearson coefficients are statistically significant at significance level of $1 \%$. This result implies the absence of multicollinearity problem.

\subsection{Methodology and Results}

In this section, we use a panel model to verify if the governance variables have an effect or not on the corporate tax planning. Our econometric procedure consists of three stages. The first one concerns the verification of the appropriate model of estimation. We have to test for the presence of individual effects of each Tunisian firm. In a second step, we specify whether the fixed effect or the random effect should be considered in estimating model parameters. The last step consists on estimating the coefficients of our variables.

We use the Fisher test, as a preliminary test, to verify the existence of individual effects in our sample. The p-value of this test entails the rejection of the null hypothesis (absence of individual effects). Therefore the Fischer test reveals the existence of specific effects across Tunisian firms. Consequently, our model is not homogeneous. 


\section{Macrothink}

International Journal of Accounting and Financial Reporting

ISSN 2162-3082

2012, Vol. 2, No. 2

Then, we use the Hausman test to specify the nature of these individual effects. Thus, the Hausman test (1978) tests the null hypothesis which stipulates that the coefficients estimated by the efficient random effects estimator are the same as the ones estimated by the consistent fixed effects estimator. (Woolridge, 2001)

According to the results presented in table 4, we notice that the p-value of Hausman test is > 0.05 which means that fixed effects are not consistent. In fact, the random effects are privileged in our study. The econometrics of the panel data allows controlling the heterogeneity of the observations of our sample of Tunisian firms in their individual dimensions by taking into account a non observable specific effect (random effects).

After setting up the effect of the econometric model, we are interested in verifying the absence of bias and problems that can affect the significance of the coefficients of the variables. We will make the necessary corrections if they exist. Among the potential problems that can arise at the time of our estimations, we quote essentially the heteroscedasticity and the multicolinearity .

We compute variance inflation factors (VIFs) when estimating our regression models to test for signs of multicolinearity between the independent variables. As no VIF exceeds five, multicolinearity is not problematic in our study (Hair et al., 2006).

Then, we apply Breusch-Pagan test to detect heteroscedasticity in our sample. The statistics of the test follows the chi square distribution. The "p-value" is less than the significance level (5\%), which leads us to reject the null hypothesis and to conclude the heteroscedasticity of our model.

To examine the association between effective tax rates and board characteristics, we estimate the following model using General least squares (GLS) to mitigate heteroscedasticity problems.

Tax planning: F (governance variables + control variables)

Effective tax rate: $\alpha_{1}+\alpha_{2}$ Duality $_{\text {it }}+\alpha_{3}$ Diversity $_{\mathrm{it}}+\alpha_{4}$ Board Size $_{i t}+\alpha_{5}$ Independent Directors $_{\text {it }}+\alpha_{6}$ Return on assets $_{i t}+\alpha_{7}$ Sector $_{i t}+\varepsilon_{i t}$

Where i represent corporations (1-32); t represent the time period and $\varepsilon$ represent the error term.

Table 5 presents the results of regressions of corporate governance coefficients obtained from the empirical estimation of equation (1). Results show that as diversity on the board increases, effective tax rates do as well. This result is consistent with the finding of Aliani \& al., (2011). We notice that the heterogeneity of the board increases divergence of opinions. Indeed, the tax decision making process will be influenced negatively and the members of the board may 
not react immediately with the turbulent tax environment.

Duality has a negative and significant sign, this coefficient shows that the duality of the CEO encourage tax planning and influences the likelihood of reducing effective tax rates' activities. This result doesn't confirm the findings of Minnick \& Noga (2010). Our result may be justified by the increasing role of the CEO/chairman; he has already all relevant information on important issues of companies, due to his full - time status and insider knowledge. The most influential members of the board are the internal directors, because they have valuable specific information about the corporate activities. Such information assists the board in making effective decision and control. (Fama, 1980; Fama \& Jensen, 1983)

This finding corroborates some authors' hypotheses. Adams (2009) suggests that the presence of intensive monitoring contribute to reducing the transfer of exhaustive information from the CEO to the independent directors. In this same line of thought, Song \& Thakor (2006) and Adams \& Ferreira (2007) show that the mission assigned to the external directors depends crucially on the nature of information provided by the CEO.

Return on assets is positively associated with effective tax rate. This result corroborates the findings of Minnick \& Noga (2010) who argue that this positive sign is expected since tax rates are progressive according to income. Wilkie (1988) argues that the income before tax is a significant determinant of the fiscal burdens variation of firms. Former research found a positive connection between the ROA and the effective tax rate. (Gupta and Newberry, 1997)

Dhaliwal and al, (1992) also suggest that the firms with greatest variability in profitability have a greater risk to make business decisions which are unsuited for their tax statute and at the same time have greater incentives to be involved in tax optimization.

The variable SEC is negative and significant; we notice that Tunisian firms belonging to the manufacturing and banking sector have the lower effective tax rates. The Tunisian state offers a favorable tax treatment of these two sectors. The heterogeneousness of corporate sectors $\mathrm{s}$ can lead to different results concerning the variability of the effective tax rates. Indeed, corporate tax burdens change from one sector to another.

The variables independent directors and board size are not significant, suggesting that the number of board's members and the percentage of independent directors had no effect on the corporate tax planning of Tunisian firms. We suggest that the presence of outside directors is not an efficient governance mechanism that enhances reduction of tax burdens.

\section{Conclusion}

This paper examines the role of corporate governance in tax planning. We adhere with agency theorists who argue that corporate governance mechanisms can play an important role in influencing and promoting corporate tax planning. (Richardson \& al., 2011; Minnick \& Noga, 2010)

We emphasized on one facet of corporate governance: board of directors. To address our research question, we create a measure (ETR) designed to reflect the tax planning strategy adopted by Tunisian firms. Using data from 2000 to 2007, we examine the association 


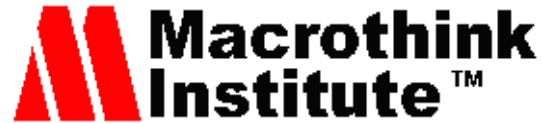

International Journal of Accounting and Financial Reporting ISSN 2162-3082

between firms' tax planning and several measures related to the board of directors such as board size, board composition and diversity

Results indicate that the Duality of CEO and diversity on the board of directors play a significant role in determining the variation of effective tax rates. However, board size and the presence of independent directors have no effect on corporate tax planning of Tunisian companies.

To our knowledge, this study represents the first attempt to empirically examine the relationship between the attributes of the board of directors and tax planning in Tunisia.

Our paper contributes to the existing literature by establishing a link between boards of directors' attributes and lower effective tax rates; we shed light into how governance is related to tax planning.

The board of directors should have the necessary expertise to mitigate the illegal tax avoidance. The Tunisian firms have to give value to female role within the company trough a better involvement in the board. Firms may not benefit from diversity of opinions and experiences in case of the presence of a weak percentage of women.

This study offers insights to firms interested in enhancing tax planning that the implementation of good corporate governance could reduce tax burdens. We propose that diversity on the board could lead to constructive tax debates if women's quota is reasonable compared to men. Also, the establishment of boards composed of professional women may ameliorate the fiscal decision making.

\section{References}

Adams, R.B. \& Ferreira, D. (2009) Women in the boardroom and their impact on governance and performance. Journal of Financial Economics, 94, 291-309.

Aliani, K., M'hamid, I. and Zarai, M. (2011) Diversité en genre dans le Conseil d'Administration et optimisation fiscale: validation dans le contexte tunisien. Global Journal of Management and Business Research, 11, 41-50.

Arlen, J. \& Weiss, D. (1995) A political theory of corporate taxation. Yale Law Journal ,105, $325-390$.

Barnhart, S. W. \& Roseinstein, S. (1998) Board Composition, Managerial Ownership, and Firm Performance: An Empirical Analysis. The Financial Review, 33, 1-16.

Beasley, M.S. (1996) An empirical analysis of the relation between the board of director composition and financial statement fraud. The Accounting Review ,71 (4), 443-465.

Crozon, R. \& Gneezy, U. (2008) Gender Differences in Preferences. Journal of Economic Literature, 47(2), 448-474.

Dalton, C. M. \& Dalton, D. R. (2005) Boards of Directors: Utilizing Empirical Evidence in Developing Practical Prescriptions. British Journal of Management, 16, 91-97.

Dhaliwal, D. \& Wang, S. (1992) The effect of book income adjustment in the 1986 alternative minimum tax on corporate reporting. Journal of Accounting and Economics, 15 (1), 7-26. 


\section{Al Macrothink}

International Journal of Accounting and Financial Reporting

ISSN 2162-3082

2012, Vol. 2, No. 2

Deli, D. \& Gillan, S. (2000) On the demand for independent and active audit committees. Journal of Corporate Finance ,6, 427-445.

Derashid, C. \& Zhang, H. (2003) Effective Tax Rates and The Industrial Policy Hypothesis: Evidence From Malaysia. Journal of International Accounting, Auditing \& Taxation, 12: 45-62.

Dyreng, S., Hanlon M. \& Maydew E. (2010) The effects of executives on corporate tax avoidance, The Accounting Review, 85 (4), 1163-1189.

Dyreng, S., Hanlon, M. \& Maydew, E. (2008) Long run corporate tax avoidance. The Accounting Review, 38, 61-82.

Erle, B. (2008) Tax risk management and board responsibility. In W. Schön, ed. Tax and Corporate Governance. Berlin Heidelberg: Springer-Verlag

Fama, E.F. \& Jensen, M.C. (1983) Separation of ownership and control. Journal of Law and Economics ,26, 301-325.

Fich, E. \& Shivdasani, A. (2007) Financial Fraud, Director Reputation, and Shareholder Wealth. Journal of Financial Economics 86, 306-336.

Graham, J. \& Tucker, A. (2006) Tax shelters and corporate debt policy. Journal of Financial Economics, 81,563-594.

Gupta, S. \& Mills, L. (2002) Corporate Mutistate Tax Planning: Benefits of Multiple Jurisdictions. Journal of Accounting and Economics ,33 (1), 117-139.

Janssen, B. Crabbe, K. \& Vanenbussche, H. (2005) Is there regional tax Competition? Firm level Evidence from Belgium. De Economist ,153,257-276.

Jensen, M.C. 1993. The modern industrial revolution, exit, and the failure of internal control systems. Journal of Finance ,48, 831-880.

Kastlunger, B., Dressler, S., Kirchler, E., Mittone, L. \& Voracek, M. (2010) Sex differences in tax compliance: Differentiating between demographic sex, gender-role orientation, and prenatal masculinization (2D:4D). Journal of economic psychology, 31,542-552

Klein, A. 2002. Audit committee, board of director characteristics, and earnings management. Journal of Accounting and Economics , 33, 375-400.

Lanis,R. \& Richardson, G. (2011) The effect of board of director composition on corporate tax aggressiveness. Journal of accounting and Public Policy, 30,50-70.

Lipton, M. \& Lorsch, J. W. (1992) A modest proposal for improved corporate governance. Business Lawyer ,48, 59-77.

Lisowsky, P., Robinson, L. \& Schmidt, A. (2010) An examination of FIN 48: tax shelters, auditor independence, and corporate governance. Working Paper, University of Illinois.

M'hamid, I. \& Hachana, R. (2010) Diversité en genre au top management, Divulgation des valeurs féminines et performance, l'exception Tunisienne. Global Journal of Strategies and Governance, 1(2), 3-23. 


\section{Al Macrothink}

International Journal of Accounting and Financial Reporting ISSN 2162-3082 2012, Vol. 2, No. 2

Minnick, K. \& Noga ,T. (2010) Do corporate governance characteristics influence tax management?. Journal of corporate finance, 16,703-718.

Omer, T.Z., Molloy,K.H. \& Ziebart,D.A. (1993) An investigation of the firm size/effective tax rate relationship in the 1980s. Journal of Accounting, Auditing and Finance, $8(2), 167-182$.

Plesko, G. (2003) An Evaluation of Alternative Measures of Corporate Tax Rates. Journal of Accounting and Economics , 35 (2), 201-226.

Porcano, T. (1986) Corporate Tax Rates: Progressive, proportional or regressive. Journal of American Taxation Association, 7 (2), 17-31.

Raffournier, B. (1990) La théorie positive de la comptabilité : Une revue de la littérature. Economies et Sociétés,16, 137-166.

Rego, S. 2003. Tax-Avoidance activities of U.S. multinational Corporations. Contemporary Accounting Research, 20, 805-833.

Richardson, G., 2007. Determinants of the variability in corporate effective tax rates and tax reform: Evidence from Australia. Journal of Accounting and Public Policy, 26 (6), 689-704.

Ross, S. 1977. The determination of financial structure: the incentive- Signal -Line Approach. Bell Journal of Economics ,8 (1), 23- 40.

Saada, T. 1993. Les déterminants des choix comptables : études des pratiques françaises et comparaison franco-américaine. Comptabilité, Contrôle et Audit, 52-74.

Singh, V. (2008) Contrasting positions of women directors in Jordan and Tunisia. In: Vinnicombe, S., Singh, V., Burke, R., Bilimoria, D. and Huse, M. (eds.) Women on Corporate Boards of Directors: International Research and Practice, 165-85. EdwardElgar, Cheltenham

Shevlin, T. (1990) Estimating corporate marginal tax rates with asymmetric tax treatment of gains and losses. Journal of the American taxation, 11,1-67.

Song, F. \& Thakor, A. (2006) Information control, career concerns, and corporate governance. Journal of Finance, 61,1845-1896.

Stickney, C. \& McGee V. (1982) Effective Corporate Tax Rates, The Effect of Size, Capital Intensity, Leverage and Other Factors. Journal of Accounting and Public Policy, 1 (2), 125-152.

Van, D. \& Steen, E. (2005) Organizational Beliefs and Managerial Vision. Journal of Law, Economics and Organization, 21, 256-283.

Vafeas, N. (2000) Board Structure and the Informativeness of Earnings'. Journal of Accounting and Public Policy, 19 (2) ,139-160.

Wilkie, P. (1988) Corporate Average Effective Tax Rates and Inferences about Relative Tax Preferences. The Journal of the American Taxation Association, 10 (1): 75-88. 
Wilson, R. (2009) An examination of corporate tax shelter participants. The accounting Review ,84, 969-999.

Yermack, D. (1996) Higher market valuation of companies with a small board of directors, Journal of Financial Economics, 40,185-211.

Yermack, D. (2004) Remuneration, Retention, and Reputation Incentives for Outside Directors. The Journal of Finance 59: 2281-2308.

Zimmerman, J. (1983) Taxes and Firm Size. Journal of Accounting and Economics 5 (1): 119-149.

\section{Appendices}

Table 1: Variable definitions

\begin{tabular}{|c|c|c|}
\hline Variables & Abbreviations & Variable definitions \\
\hline & & Tax variable \\
\hline Effective tax rate & ETR & Income tax expense/pre-tax income. \\
\hline \multicolumn{3}{|c|}{ Governance variables } \\
\hline Duality of CEO & DUA & $\begin{array}{l}\text { equal to } 1 \text { if the CEO is chair, } 0 \\
\text { otherwise }\end{array}$ \\
\hline $\begin{array}{l}\text { Diversity on the board of } \\
\text { directors }\end{array}$ & DIV & Percentage of women directors \\
\hline Independant directors & IND & $\begin{array}{l}\text { Percentage of independant directors sitting } \\
\text { on the board }\end{array}$ \\
\hline Board size & BSI & $\begin{array}{l}\text { Natural Logarithm of the number of } \\
\text { directors on the board }\end{array}$ \\
\hline \multicolumn{3}{|c|}{ Control variables } \\
\hline Return on assets & ROA & Operating result/total assets \\
\hline Sector & SEC & $\begin{array}{l}\text { SECTSERVit = } 1 \text { if the company operates } \\
\text { in the service sectorm }, 0 \text { otherwise; } \\
\text { SECTINDUSit }=1 \text { if the company } \\
\text { operates in the industrial sector, } 0 \\
\text { otherwise. }\end{array}$ \\
\hline
\end{tabular}


Table 2

\section{Descriptive statistics}

\begin{tabular}{lccc} 
Variables & n & Mean & Std.Dev \\
\hline ETR & 229 & 0.1704 & 0.1865 \\
DIV & 255 & 0.0301 & 0.0615 \\
BSI & 255 & 10.1101 & 1.8505 \\
IND & 245 & 0.8947 & 0.0531 \\
ROA & 255 & 0.0399 & 0.0727 \\
\hline
\end{tabular}

This table provides descriptive statistics on variables used in our study. Effective tax rate is a ratio of income tax expense to pre-tax income. Diversity on the board of directors is the percentage of women members of the board. Board size is the natural logarithm of the number of board members. Independent directors present the percentage of outside directors.

Table 3

Correlation Matrix for independent variables

\begin{tabular}{|c|c|c|c|c|c|c|}
\hline & DUA & DIV & ROA & BSI & IND & SECT \\
\hline DUA & 1.000 & & & & & \\
\hline DIV & $\begin{array}{l}0.1380 \\
(0.0285)^{* *}\end{array}$ & 1.000 & & & & \\
\hline ROA & $\begin{array}{l}-0.0498 \\
(0.4310)\end{array}$ & $\begin{array}{l}0.0107 \\
(0.8646)\end{array}$ & 1.000 & & & \\
\hline BSI & $\begin{array}{l}-0.0421 \\
(0.5061)\end{array}$ & $\begin{array}{l}0.2030 \\
\quad(0.0011)\end{array}$ & $\begin{array}{l}-0.1784 \\
(0.0043)\end{array}$ & 1.000 & & \\
\hline IND & $\begin{array}{c}0.1993 \\
(0.0018)\end{array}$ & $\begin{array}{c}0.3195 \\
(0.0000)\end{array}$ & -0.0467 & $\begin{array}{c}0.0786 \\
(0.4668)\end{array}$ & $\begin{array}{c}1.000 \\
(0.2204)\end{array}$ & \\
\hline SEC & $\begin{array}{c}0.1936 \\
(0.0020)\end{array}$ & $\begin{array}{l}-0.0407 \\
(0.5173)\end{array}$ & $\begin{array}{l}-0.2524 \\
(0.0000)^{* * *}\end{array}$ & $\begin{array}{l}0.1473 \\
(0.0186)\end{array}$ & $\begin{array}{l}-0.0719 \\
\quad(0.2622)\end{array}$ & 1.000 \\
\hline
\end{tabular}


Table 4

\section{Results of Hausman test}

\section{Hausman test}

\begin{tabular}{|l|l|}
\hline Null Hypothesis & Difference in coefficients not systematic \\
\hline Prob>chi2 & 0.5940 \\
\hline
\end{tabular}

Table 5

Effect of the board on corporate tax planning

\begin{tabular}{|c|c|c|}
\hline \multirow[t]{2}{*}{ Independent variables } & \multicolumn{2}{|c|}{ Dependent variable : tax planning } \\
\hline & Coefficients & p-value \\
\hline DUA $_{(i t)}$ & -0.055 & 0.093 \\
\hline $\mathrm{DIV}_{(\mathrm{it})}$ & 0.827 & 0.000 \\
\hline $\mathrm{IND}_{\text {(it) }}$ & 0.053 & 0.797 \\
\hline $\mathrm{BSI}_{(\mathrm{it})}$ & -0.017 & 0.766 \\
\hline $\mathrm{ROA}_{(\mathrm{it})}$ & 0.508 & 0.001 \\
\hline $\mathrm{SEC}_{(\mathrm{it})}$ & 0.133 & 0.000 \\
\hline Constant (it) & 0.071 & 0.773 \\
\hline Wald Khi (5) & 43.09 & 0.000 \\
\hline
\end{tabular}

